\title{
The Government Can't, May, or Must Fund Religious Schools: Three Riddles of Constitutional Change for Laurence Tribe
}

\section{Citation}

Martha Minow, The Government Can't, May, or Must Fund Religious Schools: Three Riddles of Constitutional Change for Laurence Tribe, 42 Tulsa L. Rev. 911 (2006).

\section{Published Version}

http://digitalcommons.law.utulsa.edu/ttr/vol42/iss4/9/

\section{Permanent link}

http://nrs.harvard.edu/urn-3:HUL.InstRepos:12052192

\section{Terms of Use}

This article was downloaded from Harvard University's DASH repository, and is made available under the terms and conditions applicable to Other Posted Material, as set forth at http:// nrs.harvard.edu/urn-3:HUL.InstRepos:dash.current.terms-of-use\#LAA

\section{Share Your Story}

The Harvard community has made this article openly available. Please share how this access benefits you. Submit a story.

Accessibility 


\section{Tulsa Law Review}

Volume 42

Issue 4 The Scholarship of Laurence Tribe

Article 9

2007

The Government Can't, May, or Must Fund Religious Schools: Three Riddles of Constitutional Change for Laurence Tribe

Martha Minow

Follow this and additional works at: http://digitalcommons.law.utulsa.edu/tlr

Part of the Law Commons

\section{Recommended Citation}

Martha Minow, The Government Can't, May, or Must Fund Religious Schools: Three Riddles of Constitutional Change for Laurence Tribe, 42 Tulsa L. Rev. 911 (2006).

Available at: http://digitalcommons.law.utulsa.edu/tlr/vol42/iss4/9

This Legal Scholarship Symposia Articles is brought to you for free and open access by TU Law Digital Commons. It has been accepted for inclusion in Tulsa Law Review by an authorized administrator of TU Law Digital Commons. For more information, please contact daniel-bell@utulsa.edu. 


\title{
THE GOVERNMENT CAN'T, MAY, OR MUST FUND RELIGIOUS SCHOOLS: THREE RIDDLES OF CONSTITUTIONAL CHANGE FOR LAURENCE TRIBE
}

\author{
Martha Minow*
}

\section{INTRODUCTION}

In a 1975 article, Laurence Tribe explored how three separate puzzles of constitutional law might seem more solvable when viewed together. ${ }^{1}$ It was an arresting claim, especially as puzzle designers ratchet up levels of difficulty when they combine two or more puzzles into one. ${ }^{2}$ Tribe's use of joint riddles to solve problems is mirrored in recent scientific work joining computational biology and genetics. Scientists in those fields proceed with the hope that a difficult problem can be understood, if not resolved, by locating it as a part of a bigger problem. ${ }^{3}$ In that hope, and inspired by the scholarship and advocacy of Professor Tribe, I tackle here quandaries of constitutional change surrounding the constitutionality of public funding for private schools-where the funding scheme excludes religious schools. Three puzzles become unavoidable: How can the demands of both the Establishment and Free Exercise clause be satisfied;

* Jeremiah Smith, Jr., Professor, Harvard Law School. Special thanks to Cass Sunstein, Robert Post, and Reva Siegel for helpful comments, and to Larry Tribe for friendship and inspiration.

1. Laurence H. Tribe, Childhood, Suspect Classifications, and Conclusive Presumptions: Three Linked Riddles, 39 L. \& Contemp. Probs. 8 (1975).

2. Bob Armstrong, Earliest Use of Special Techniques for Making Adult Jigsaw Puzzles, 3 Game \& Puzzle Collectors Q. (2002). One jigsaw puzzle, advertised as the most difficult in the world, is described this way:

This is no ordinary jigsaw puzzle! It's an insane, double sided puzzle which has the same artwork on both sides, but offset $90^{\circ}$ from each other. This puzzle is made from fine linen paper and premium brand board that's distınctively tinted to showcase its quality and thickness. Buffalo Games uses environmentally friendly soy based inks. Each piece is easy to hold, easy to see, and "snaps" together. Pieces come within a poly-bag and shrink-wrapped box.

Cats 500 pcs, http:/www. hobbylinc.com/htm/buf/buf858.htm (accessed Feb. 25, 2007).

3. Robert L. Glass, Practical Programmer: Is This a Revolutionary Idea, or Not? 47 Commun. ACM 23, 23-24 (2004) (available at http://delivery.acm.org/10.1145/1030000/1029514/p23glass.html?keyl $=1029514 \&$ key $2=9102025711 \&$ coll=\&dl=GUIDE\&CFID $=15151515 \&$ CFTOKEN=6184618) (exploring possible software construction by simultaneous work on parallel behavior trees-addressing components (the software pieces), states (that those components can take on), events and decisions/constraints (that are associated with the components), data that the components exchange, and the causal, logical, and temporal dependencies (associated with component interactions)); Edward M. Marcotte, Assembling a Jigsaw Puzzle with 20,000 Parts, 4 Genome Biology 323 (2003) (available at http://www.pubmedcentral.nih.gov/ articlerender.fcgi?artid=193613) (exploring use of algorithms that to identify peptides from experimental peptide fragmentation spectra in post-transformational states and studies of protein-protein interactions that start with an algorithm that finds amino-acid sequences that pack well into a fixed protein structure, and create a new interface between two DNA-binding domains of known structure). 
what does respecting precedent mean when there is a recent reversal of one line of cases; and when does federalism demand deference to the supremacy of the federal constitution or instead respect for state autonomy?

Although he addressed childhood, suspect classifications, and conclusive presumptions, Professor Tribe's own proposal for dealing with his three puzzles reverberates in the analysis of these issues. As he called for selective judicial invalidation of certain conclusive presumptions-ensuring individualization in government treatment of minors in some contexts-Professor Tribe characterized his approach as a kind of "antidoctrine" reflecting social and political transition, moral uncertainty, and marking how the courts would "facilitate, and take part in, the evolution of moral-and thus legal-consciousness." I suggest here that the Constitution's demands will not be resolved through a new three-part test or other doctrinal solution, but instead through particularized case-by-case judicial attention to the cumulative impact of religious schooling on the character of the nation and the predicates for inclusive democracy. Even though case-by-case decision-making allows for mistakes and produces uncertainty, it also permits evolving and practical responsiveness to the multiple priorities relevant to religion, schooling, and democracy.

\section{PuZZle I: RElating THE FreE EXeRCISE AND Establishment ClausES}

The first puzzle concerns the relationship between the Free Exercise Clause and the Establishment Clause in addressing public aid reaching religious schools. Without a clear answer from history, text, or doctrine, government actors must somehow simultaneously protect the free exercise of religion by individuals, even those without mainstream practices, and avoid making any law "respecting" the establishment of religion. $^{5}$ The central difficulty arises if a government official or agency devises an accommodation, exempting members of a particular religion from an otherwise-

4. Tribe, supra n. 1 , at 37 .

5. U.S. Const. amend. I: "Congress shall make no law respecting an establishment of religion, or prohibiting the free exercise thereof." Social, political, and legal changes make the religion clauses particularly illustrative of the inevitability of changing constitutional interpretation. Even if there were agreement about the framers' conceptions of the First Amendment's treatment of religion, changes in society and government since the adoption of the Bill of Rights prevent straight-line continuity of interpretation. Justice Brennan has emphasized how the contemporary religious heterogeneity far surpasses the diversity at the time of the founding generation. Sch. Dist. of Abington Township v. Schempp, 374 U.S. 203, 230 (1963) (Brennan, J., concurring). As a result, Justice Brennan rejected the very focus on historical aims and instead argued that for an inquiry into whether the challenged practices threaten "those consequences which the Framers deeply feared; whether, in short, they tend to promote the type of interdependence between religion and state which the First Amendment was designed to prevent." Id. at 236. There is, of course, far greater religious diversity in the United States now than when Justice Brennan wrote that opinion. See generally Barry A. Kosmin, Egon Mayer \& Ariela Keysar, American Religious Identification Survey 10, http://www.gc.cuny.edu/faculty /research_studies/aris.pdf (last updated Dec. 19, 2001) ("[T]he proportion of the [American] population that can be classified as Christian has declined from eighty-six in 1990 to seventy-seven percent in 2001."). This trend reflects both growing presence of Muslims, Hindus, and Buddhists, the increasing self-identification of Native Americans, and the rapidly rising number of people who claim no religious identity. See Diana L. Eck, A New Religious America: How a "Christian Country" Has Become the World's Most Religiously Diverse Nation (Harper S.F. 2001); Cathy Grossman, Charting Unchurched America, USA Today 01d (Mar. 7, 2007) (Fourteen percent of the nation does not follow any organized religion, almost double the eight percent reported in 1990.). The expansion of government-producing many more occasions for potential contact between religion and government-is another crucial change. See William W. Van Alstyne, Constitutional Separation of Church and State. The Quest for a Coherent Position, 57 Am. Political Sci. Rev. 865, 881 (1963). 
prevailing rule ${ }^{6}$ - for that very effort to allow free exercise of religion could be viewed as an impermissible preference. ${ }^{7}$ Some "play in the joints" seems necessary for the commitments both to free exercise and to avoiding preference for religion, ${ }^{8}$ but how much?

This problem, difficult enough in the abstract, supplies the constitutional terrain for decades of intense battles over public aid to parochial schools in the United States. Parents seeking to provide religious education for their children are assured that prerogative, ${ }^{9}$ but governments seeking to assist those parents, or merely to provide a "level playing field" rather than a government preference for secular instruction, run into the Establishment Clause. Whether in the form of subsidies for teachers and materials or tuition relief for students, public aid to parochial schools for several decades triggered judicially-enforced Establishment Clause barriers on two grounds: 1) Public money must not directly reach pervasively sectarian institutions; ${ }^{10}$ and 2) Public aid must not even indirectly reach parochial schools if that would allow diversion of funds into religious indoctrination.

This strict separationist view, developed in the mid-twentieth century, did not halt continuing efforts to provide aid to religious schools or parents selecting them-and constitutional arguments on their behalf. ${ }^{11}$ Pro-aid forces can mount a free exercisestyle objection for interfering with the option of religious schooling that some parents may believe necessary or desirable. ${ }^{12}$ Especially where the local or state government finances public schools, a special burden falls on parents or students who must pay out of their own pockets if they seek to combine schooling with religious instruction for their children. This burden on individual choice becomes especially pronounced where the government offers funds to individuals choosing private education but only if it is not religious:

The selective denial discourages religious-school choices and, at least prima facie, communicates disfavor of them .... [A] satisfactory K-12 education in math, English, and history in a religious school imparts secular knowledge and provides significant secular

6. Hobbie v. Unempl. Apps. Commn., 480 U.S. 136, 144-45 (1987); Sherbert v. Verner, 374 U.S. 398, 409 (1963). Recently, a public school coach faced the conflict when the school board, following complaints by some parents, prohibited his participation in student-led team prayers; a district court judge concluded that the coach could participate-but did so in part by suggesting that the coach would not be praying but instead providing leadership for the team. See Associated Press, Court's Call: N.J. Coach Can 'Take a Knee' While Team Proys, http://www. firstamendmentcenter.org/news.aspx?id=17207 (July 27, 2006).

7. The preference could seem to run to members of a particular religion or to religion in general; either would run afoul of the Establishment Clause.

8. See Walz v. Tax Commn. of the City of N.Y., 397 U.S. 664, 668-69 (1970) ("[T] here is room for play in the joints productive of a benevolent neutrality which will permit religious exercise to exist without [governmental] sponsorship and without interference.").

9. See Wis. v. Yoder, 406 U.S. 205 (1972); Pierce v. Soc. of Sisters, 268 U.S. 510 (1925). Both of these cases invoke substantive due process as a frame for the parental right, but both also reflect free exercise considerations.

10. Bowen v. Kendrick, 487 U.S. 589, 609-10 (1988). Four members of the Court rejected this view in a plurality opinion in Mitchell v. Helms, 530 U.S. 793, 809-10 (2000).

11. Starting with Everson v. Bd. of Educ. of the Township of Ewing, 330 U.S. 1 (1947), the Supreme Court interpreted the Establishment Clause to guard the governmental raising of tax revenues to support religious instruction or institutions.

12. See Thomas C. Berg \& Douglas Laycock, The Mistakes in Locke v. Davey and the Future of State Payments for Services Provided by Religious Institutions, 40 Tulsa L. Rev. 227 (2004). 
value to society-yet a state exclusion of religious schools withholds benefits even for that unquestionable educational contribution. The family is not merely denied assistance for religious teaching, but is penalized for choosing to pursue its child's basic $\mathrm{K}-12$ education in a religious setting. ${ }^{13}$

Governments act unacceptably if they target specific religious groups for disapproval. ${ }^{14}$ Historic antagonism over Catholic schools exacerbates the potential constitutional difficulty with school subsidy programs that exclude religious schools by suggesting an impermissible animus motivated the statutory and constitutional rules against any public dollars ever reaching a private religious school. ${ }^{15}$ The exclusion of religious schools from the set of educational options accorded public funding could raise constitutional concerns on both free exercise and viewpoint discrimination grounds. ${ }^{16}$

The chief defense that governments supply after excluding religious schools from funding available to other schools is their concern to avoid violating legal restrictions on government aid to religion. This defense crumbles if the Establishment Clause is reinterpreted to permit public funds to reach pervasively sectarian parochial schools when part of a general, neutral scheme; indeed, then the strict separation approach becomes unnecessary-and the tension with free exercise, viewpoint discrimination, and the prohibition against targeting religions for negative treatment each disappear. The general scheme could offer aid for secular activities at any school, or aid to parents and students who select any accredited school-including a religious one. Arguably, through such programs, the government would not be endorsing or advancing religion or any particular religion. Instead, a general scheme through which the government makes books and computers available to all schools, or extends vouchers to parents who select a

13. Thomas C. Berg, Why a State Exclusion of Religious Schools from School Choice Programs Is Unconstitutional, 2 First Amend. L. Rev. 23, 27 (2003). An early effort to develop this argument appears in Michael W. McConnell, The Selective Funding Problem: Abortions and Religious Schools, 104 Harv. L. Rev. $989,1017-18,1046-47(1991)$. For an argument that rights of religious people in general face greater threats in the United States than rights of secularists, see Joseph P. Viteritti, The Last Freedom: Religion from the Public School to the Public Square (Princeton U. Press 2007).

14. Church of Lukumi Babalu Aye, Inc. v. City of Hialeah, 508 U.S. 520 (1993).

15. See generally Thomas C. Berg, Anti-Catholicism and Modern Church-State Relations, 33 Loy. U. Chi. L.J. 121 (2001). Moreover, the exclusion of religious schools from public subsidy programs may seem to or actually fall most heavily on poor urban students of color, who face either failing public schools or better parochial (usually Catholic) private schools. See generally Joseph P. Viteritti, Choosing Equality: School Choice, the Constitution, and Civil Society (Brookings Instn. 2001). Catholic schools started largely as an effort to maintain religious identity and avoid "an unwelcome assimilation," McConnell, supra n. 13, at 1043, but "[i]t would be difficult to prove that the government's only reason for continuing to refuse to fund religious schools is to induce religious assimilation." Id. at 1045.

16. On free exercise, see Nathan Lewin, How School Vouchers Can Win in the Supreme Court: Distinguishing "What" from "How" in Aid to Religious Schools, http://www.jlaw.com/Articles/ SchoolVouchers.html (accessed Feb. 25, 2007). On viewpoint discrimination, see Good News Club v. Milford C. Sch., 533 U.S. 98 (2001); Rosenberger v. Rector \& Visitors of the U. of Va., 515 U.S. 819 (1995); Widmar v. Vincent, 454 U.S. 263 (1981). In each instance, a public university or school had excluded religious groups from using the institution's space or resources and explained such exclusions as efforts to avoid Establishment Clause violations, and in each case, the Court rejected the Establishment Clause rationale, and found the exclusionary policies forms of impermissible viewpoint discrimination, violating the free speech guarantee of the Constitution. For an argument that this equal treatment approach undermines the special significance of religion by equating religious expression with any other kind of expression, see Derek $\mathrm{H}$. Davis, $A$ Commentary on the Supreme Court's "Equal Treatment" Doctrine as the New Constitutional Paradigm for Protecting Religious Liberty, 46 J. Church \& St. 717, 735-36 (2004). See generally Equal Treatment of Religion in a Pluralistic Society (Stephen V. Monsma \& J. Christopher Soper eds., Eerdmans Publg. Co. 1998). 
parochial school from a set of school options, advances equal regard for religious and secular options.

This is undeniably a period of shifting judicial treatment of religion in the United States, with particularly unsettled results for both the analysis of and outcomes in Establishment Clause challenges to government action. Federal courts have recently approved decisions by governments to provide religious groups access to programs open to others and rejected governmental exclusions of religious groups from generally available public resources. ${ }^{17}$ For example, the Court found no Establishment Clause problem with a school voucher program, allowing low-income parents to select religious schools from among a range of schooling options. ${ }^{18}$ A fractured Court permitted public display of the Ten Commandments in one setting but not in another. ${ }^{19}$ As a sign of shifting priorities, the Department of Justice Civil Rights Division under the administration of President George W. Bush devoted resources to challenge religious discrimination while reducing attention to racial discrimination. ${ }^{20}$ A closely divided Court closed off the avenue for taxpayers to challenge the White House Office of FaithBased and Community Initiatives, which plaintiffs had argued steered public funds to groups with strong political affiliations. ${ }^{21}$

The Supreme Court did hold onto one remnant of the old separatist view by stressing that parents, not state actors, selected the religious schools from the range of schooling options. ${ }^{22}$ Now, the question left open is whether the federal Constitution demands the inclusion of religious schools in a voucher program-or demands public aid to facilitate the selection of parochial schooling, when public support is available for other kinds of schooling. Now allowed by the Establishment Clause, are voucher programs that encompass religious schools compelled even in cities and states that prefer to confine school voucher programs to nonreligious schools? ${ }^{23}$ Exclusion of religious

17. See e.g. Good News Club, 533 U.S. 98; Rosenberger, 515 U.S. 819; Widmar, 454 U.S. 263. In each instance, a public university or school had excluded religious groups from using the institution's space or resources and explained such exclusions as efforts to avoid Establishment Clause violations, and in each case, the Court rejected the Establishment Clause rationale, and found the exclusionary policies forms of impermissible viewpoint discrimination, violating the free speech guarantee of the Constitution. For an argument that this equal treatment approach undermines the special significance of religion by equating religious expression with any other kind of expression, see Davis, supra n. 16, at 235-36.

18. Zelman v. Simmons-Harris, 536 U.S. 639 (2002).

19. See Linda Greenhouse, Justices Allow a Commandments Display, Bar Others, N.Y. Times A1 (June 28, 2005).

20. Neil A. Lewis, Justice Dept. Reshapes Its Clvil Rights Mission, http://www.nytimes.com/2007/06/14/ washington/14discrim.html?ei=5088\&en $=589474 \mathrm{~d} 3 \mathrm{~b} 5 \mathrm{dc} 75 \mathrm{df \& ex}=1339473600$ \& partner $=r$ \& \& pagewanted=all (June 14, 2007).

21. The Court ruled 5-4 that the challengers lacked standing to sue because the funds came from general appropriations, not specific legislation. Hein v. Freedom from Religion Found., $127 \mathrm{~S}$. Ct. 2553 (2007). Two members of the Court indicated that they would overtum the precedent authorizing taxpayers' suits in specific Establishment Clause contexts. The practical effect of the decision will be to permit the executive to promote funding to religious groups without judicial oversight. See Michael Kranish, Court Bars Suit on Faith-Based Plan, Boston Globe A1 (June 26, 2007). Each of the opinions in the case underscore the enforcement barriers that accompany Establishment Clause challenges to the use of public appropriations.

22. Zelman, 536 U.S. 639.

23. See David Heim, Vouch for It? -School Voucher Plans and Religious Schools, Christian Cent. (July 29, 1998) (available at http://findarticles.com/p/articles/mi_m1058/is_n21_v115/ai_21043675/pg_1). The Florida Supreme Court declined to embrace similar free exercise arguments offered to defend the country's first statewide school choice program; the Florida Opportunity Scholarships violated the state constitution's 
schools from public aid looked not only permissible but required when the base-line was strict separation between religion and government across all kinds of settings; but now that public bodies can fund vouchers redeemable at religious schools, the exclusion of religious schools from local schemes may come to be seen as an expression of unfair discrimination or impermissible animus.

\section{Puzzle II: Respecting Precedent When the Court Reverses a Precedent}

The second puzzle arises from the continually difficult subject of stare decisis: When should and when must a court adhere to its prior decisions, given the competing goods of predictability - which enhances liberty, fairness, and the rule of law ${ }^{24}$-and flexibility due to changing circumstances and evolving understandings of justice? An acute version of Puzzle Two emerges when the Supreme Court reverses a precedent; then, in the name of stare decisis, how strongly should courts adhere to and extend a new decision reversing prior precedent, and how much instead should judges pace doctrinal change by adhering to prior precedents in neighboring areas? ${ }^{25}$

This puzzle is especially evident since the recent treatment of the Establishment Clause, which one commentator describes as "the crumbling wall of separation between church and state," 26 a collapse increasingly permitting public aid to religious schools. In 1997, the Court overturned an earlier decision that forbade publicly paid teachers to go onto parochial school premises to teach remedial reading and instead ruled that even direct aid to a religious school could comply with the Establishment Clause ${ }^{27}$ A plurality opinion in 2000 produced a dramatically different analysis that would permit public resources to reach religious schools as long as the aid itself would be secular and would proceed in a neutral manner, available to public and private, secular and religious schools, ${ }^{28}$ but this view did not persuade a majority of the Court. Other Justices writing

"uniformity" clause guaranteeing all state students a "uniform, efficient, safe, secure, and high quality system of free public" education. See Lisa Knepper, Florida Supreme Court Strikes Down School Choice, http://www.ij.org/schoolchoice/florida/1_5_06pr.html (last updated Jan. 5, 2006).

24. See Planned Parenthood v. Casey, 505 U.S. 833, 844 (1992) (plurality) ("Liberty finds no refuge in a jurisprudence of doubt.").

25. An external perspective on the Supreme Court would of course emphasize the effects of changing membership on the stability of precedent. So would a journalistic perspective. See Linda Greenhouse \& David D. Kirkpatrick, Justices Loosen Ad Restrictions in Campaign Law, N.Y. Times A1, A 18 (June 26, 2007); Linda Greenhouse, Vote Against Banner Shows Divide on Speech in Schools, N.Y. Times A18 (June 26, 2007) (relating revision of 2003 decision to changing Court membership). For a cogent discussion about internalist and extemalist perspectives, see Mark Tushnet, Review: The New Deal Constitutıonal Revolution: Law, Politics, or What? 66 U. Chi. L. Rev. 1061 (1999).

26. Amit Patel, The Orthodoxy Opening Predicament: The Crumbling Wall of Separation between Church and State, 83 U. Det. Mercy L. Rev. 195 (2006). Another author asserts that a recent decision "razed the wall" between Church and State. Jason S. Marks, Only a "Speed Bump" Separating Church and State? 57 J. Mo. Bar 1 (Jan.-Feb. 2001) (available at http://www.mobar.org/journal/2001/janfeb/marks.htm) (discussing how the plurality opinion in Mitchell $v$. Helms would overnule both the result and the reasoning of Meek $v$. Pittinger and Wolman v. Walter, dispense with the long-standing distinction between indirect government aid (permitted) and direct government aid to religious institutions (forbidden), and focus solely on whether "the aid itself has an impermissible content" rather than whether it allows funds to be diverted to support religious practice or indoctrination). Justices Scalia and Thomas are ready to overturn other precedents in the religion context. See e.g. Hein, 127 S. Ct. at 2573 (Scalia \& Thomas, JJ., concurnng).

27. Agostini v. Felton, 521 U.S. 203 (1997) (overturning Aguilar v. Felton, 473 U.S. 402 (1985)).

28. See generally Mitchell, 530 U.S. 793. The Court had already reopened an older case and reversed course, permitting federally funded remedial instruction to take place on the site of a parochial school. See 
separately urged retention of key elements of the separationist doctrinal inquiry into whether the government is impermissibly giving direct aid to religious practice or indoctrination. ${ }^{29}$ In 2002, a full majority of the Court upheld a city program funding school vouchers used primarily in religious schools, ${ }^{30}$ but the opinion for the Court included many qualifications, confining the decision to retain elements of the separationist view. Commentators since have understandably disagreed whether these cases amount to revolutionary change or small nuances. ${ }^{31}$ The decisions leave unanswered basic questions about the relationship between public funding and religious schools, including whether a public funding program must include religious schools when other schools are eligible, ${ }^{32}$ and whether adherence to the new precedents ends the rigorous scrutiny associated with the separationist approach and replaces it with a neutral treatment analysis.

However these questions will be resolved, the Court and commentators will be reacting to the confusion created by prior legal doctrine. The older precedents direct judicial inquiry, first announced in Lemon v. Kurtzman, ${ }^{33}$ into whether the government aid directly and impermissibly funds religious practice or indoctrination, or instead permissibly provides indirect assistance, allows individuals to choose religious programs, or supports solely secular activities without shifting fungible funds to religious activities.

Agostini, 521 U.S. 203 (reversing prior judgment in Aguilar, 473 U.S. 402, and its companion case, Sch. Dist. of Grand Rapids v. Ball, 473 U.S. 373 (1985)).

29 Mitchell, 530 U.S. at 836 (O'Connor \& Breyer, JJ., concurring).

30. Zelman, 536 U.S. 639. Many factors contributed to the Supreme Court's approval of the voucher scheme in Zelman:

1) it covered only disadvantaged students;

2) in a dismally failing public school district;

3 ) it included genuine secular options;

4) it offered no financial incentives for selecting the religious schools over other options; and

5 ) it offered public aid only indirectly, after parents selected the religious school

Id. at 662 . And Justice $\mathrm{O}$ 'Connor, while not confining her vote in the five-person majority to the reasons stated in her concurring opinion, did additionally emphasize these features:

6) the support that the Cleveland voucher program provides religious institutions support is not

substantial and that is not atypical of other existing govemment programs.

Id. at 668 (O'Connor, J., concurring). It is far from clear why the first two factors offer any resolution of the religious clause questions, even though they well explain by the political support for the voucher program and some of the motivation for change in judicial resistance to aid to religious schools.

31. Compare Barbara Bradley Hagerty, ADF a Force behind Conservative Court Victories, http://www.npr.org/templates/story/story.php?storyld=4633563 (Sept. 10, 2007) (Jordan Lorance of Alliance Defense Fund sees "180-degree change" in the Supreme Court's treatment of Establishment Clause challenges) with Richard E. Morgan, The Failure of the Rehnquist Court, Claremont Inst. 3 (Spring 2006) (available at http://www.claremont.org/publications/crb/1d.1007/article_detail.asp) (seeing only small course corrections in Establishment Clause cases).

32. The public funding may be for tuition vouchers or instead it may take the form of a tax credit. Further questions arise when the school options include public charter schools organized as religious schools. See Mary Elizabeth Hill Hanchey, Resisting Efforts to Provide Public Funding for Parochial Education in Wake of Zelman v. Simmons-Harris: A Primer for North Carolina Advocates, 1 First Amend. L. Rev. 85, 104-10 (2003) (considering how possible creation of publicly-chartered religious schools raises the problem of direct aid to parochial school on a per-pupil basis; revising the charter school to give funding to parents who then choose the religious charter schools could avoid constitutional problem).

33. 403 U.S. 602 (1971). 
Using these inquiries, the Supreme Court produced a notoriously inconsistent set of decisions interpreting the Establishment Clause, ${ }^{34}$ while states and localities tested these legal limits and tried to accommodate parents selecting religious schools.

Justices O'Connor and Breyer reinforced these precedents and the Lemon test in supplying the crucial votes requiring the inclusion of religious schools in the public subsidy program at issue in Mitchell v. Helms. ${ }^{35}$ There, Justices O'Connor and Breyer reasoned that while neutrality in the sense of evenhandedness and secular content are relevant to Establishment Clause inquiries, a program would remain defective if it permitted diversion of resources to give direct support to religious indoctrination, or lacked the intervention of a private individual choosing to use the resources for that purpose. $^{36}$ The four other members of the Court who agreed with this result pushed instead for the new test for government neutrality in offering aid of secular content; this would suffice, in their view, to satisfy the Establishment Clause and no court would need to ask whether aid reaches schools that are pervasively sectarian or whether the aid allows religious schools to divert funds to purely religious activities. ${ }^{37}$ Laying the ground for the Court's later decision to permit inclusion of religious schools in a voucher program, the plurality opinion reasoned that "if the government, seeking to further some legitimate secular purpose, offers aid on the same terms, without regard to religion, to all who adequately further that purpose, ... then it is fair to say that any aid going to a religious recipient only has the effect of furthering that secular purpose.",38

When the full Court majority, over four dissents, later approved the school voucher program, the crucial concurring opinion by Justice O'Connor still preserved the distinction between direct and indirect aid-and emphasized that the program placed the government aid in the hands of parents, who then could make their own choice of

34. Over a dozen Supreme Court cases between 1968 and 2005 address public aid to nonpublic education in light of the religion clauses. See Geoffrey R. Stone, Louis M. Seidman, Cass R. Sunstein \& Mark V. Tushnet, Constitutional Law 1531 (5th ed., Aspen 2005). Seeking to stop public aid from supporting a pervasively religious institution, the Court disallowed: Aid to parochial schools for supplementing salaries of teachers of secular subjects; aid for counseling, testing, and psychological services, speech and hearing therapy; teaching and related services tax credits for low-income parents and tax deduction for high-income parents each sending their children to parochial schools; and reimbursement of costs involved in administered state tests at parochial schools. See Meek v. Pittinger, 421 U.S. 349 (1975); Comm. for Pub. Edu. v. Nyquest, 413 U.S. 756 (1973); Levilt v. Comm. for Pub. Educ., 413 U.S. 472 (1973); Lemon, 403 U.S. 602. The notion of strict separation reflected both a kind of anti-contamination principle and also a practical economic idea that relieving the burden of the secular activities from the religious school's budget so remaining funds could be devoted to religious activities. The Court over the same time period permitted public aid in the form of secular textbooks loaned to parochial schools, public school personnel administering at neutral sites diagnostic tests and services for parochial school students; and reimbursement of costs associated with state-mandated tests. Comm. for Pub. Educ. v. Regan, 444 U.S. 646 (1980); Wolman v. Walter, 433 U.S. 229 (1977); Bd. of Educ. v. Allen, 392 U.S. 236 (1968).

35. 530 U.S. at 836 (O'Connor \& Breyer, JJ., concurring).

36. Id. at $840-44$.

37. Id. at 801 . Here the plurality marked a transition, using elements of the test from Lemon, 403 U.S. 602 , while moving toward an equal treatment approach. Establishing the line between permitted and forbidden government support benefiting parochial schools proved difficult to draw, as did the relationship between forbidden and required accommodation of religious free exercise. The Lemon test inspired so many criticisms that one author announced, "Lemon is Dead." Michael Stokes Paulsen, Lemon is Dead, 43 Case W. Res. L. Rev. 795 (1993). By 1993, five members of the Supreme Court condemned the Lemon test. See Lamb's Chapel v. C. of Moriches Union Free Sch. Dist., 508 U.S. 384, $399-400$ (1993) (Scalia \& Thomas, JJ., concurring).

38. Mitchell, 530 U.S. at 810. 
religious or secular schools. ${ }^{39}$ Since the deciding vote was cast by a Justice who is no longer on the Court, the status of these distinctions to future Establishment Clause analysis remains in doubt. ${ }^{40}$ This period of change and transition on the Court signals shifting political and moral views as well as changing legal doctrine, with inevitable dialogue between past and present without generating a new dominant view. 41

Changes in judicial treatment of the Free Exercise Clause have been if anything more sweeping. The Court's decision in Employment Division v. Smith completely replaced strict scrutiny with a rational basis analysis of generally applicable laws. ${ }^{42}$ Yet even the new Free Exercise analysis does not answer how to treat a scheme, ostensibly general, that substantially skews private choices toward religious schools. ${ }^{43}$ Such a scheme could raise Establishment Clause concerns about government action that a reasonable observer would view as a governmental endorsement of religion in general or of a particular religion. ${ }^{44}$ When combined with the still uncertain scope of the changing

39. Zelman, 536 U.S. at 672 (O'Connor, J., concurring). Justice O'Connor, whose vote was necessary for the majority, wrote separately and emphasized that "Cleveland parents who use vouchers to send their children to religious private schools do so as a result of true private choice" from an array including nonreligious public and community schools. Id.

40. For a prediction, see Joseph N. Knippenberg, John Roberts on Church and State: A Speculative Reconstruction, http://www.ashbrook.org/publicat/oped/knippenberg/05/roberts.html (last updated Aug. 2005).

41. Cf. Tribe, supra n. 1, at 25 (describing shifting views about sex roles and parenting, without a crystallizing moral consensus).

42. Compare Smith, 494 U.S. 872 (halting heightened scrutiny to the government's refusal to grant exemptions to generally applicable laws that unintentionally burden religious beliefs or practices) with Sherbert, 374 U.S. 398 (requiring strict scrutiny of employment compensation rule which failed to accommodate an individual who observed the Sabbath on Saturday).

43. The possibility that financial incentives would skew private choices toward the religious option concerned even the Court's majority in Zelman, where the Justices in the majority simply concluded that the array of choice and financial terms produced no such impermissible effect. 536 U.S. at 622-23.

44. In Zelman, 536 U.S. at 654-55, Chief Justice Rehnquist's opinion dealt with an objection on this ground by indicating the facts did not support it:

Respondents suggest that even without a financial incentive for parents to choose a religious school, the program creates a "public perception that the State is endorsing religious practices and beliefs." But we have repeatedly recognized that no reasonable observer would think a neutral program of private choice, where state aid reaches religious schools solely as a result of the numerous independent decisions of private individuals, carries with it the imprimatur of government endorsement. The argument is particularly misplaced here since "the reasonable observer in the endorsement inquiry must be deemed aware" of the "history and context" underlying a challenged program. Any objective observer familiar with the full history and context of the Ohio program would reasonably view it as one aspect of a broader undertaking to assist poor children in failed schools, not as an endorsement of religious schooling in general.

Id. (citations omitted), Justice $O^{\prime}$ Connor introduced the reasonable observer perspective to assess such skewing and also to assess when the government impermissibly endorses religion. See e.g. Rosenberger, 515 U.S. at 848 (O'Connor, J., concurring).

In Witters v. Wash. Dept. of Servs. for Blind, 474 U.S. 481 (1986), for example, we unanimously held that the State may, through a generally applicable financial aid program, pay a blind student's tuition at a sectarian theological institution. The Court so held, however, only after emphasizing that "vocational assistance provided under the Washington program is paid directly to the student, who transmits it to the educational institution of his or her choice." The benefit to religion under the program, therefore, is akin to a public servant contributing her government paycheck to the church. We thus resolved the conflict between the neutrality principle and the funding prohibition, not by permitting one to trump the other, but by relying on the elements of choice peculiar to the facts of that case: "The aid to religion at issue here is the result of petitioner's private choice. No reasonable observer is likely to draw from the facts before us an inference that the State itself is endorsing a religious practice or belief." 
interpretation of the Establishment Clause, developments in Free Exercise doctrine further complicate the task of a court determined to follow precedent strictly. ${ }^{45}$ Which line should remain fixed in the judicial decision-making: The line outlawing general aid programs that exclude religious schools, or the line rejecting government policies that push people into religion?

The Court has made room for greater public support of religious institutions than in the past, but left uncertain when such public support ought to be compelled, and if so, whether the governing theory would be Free Exercise of religion (because exclusion from public resources would unduly burden such private exercise), or instead Free Speech (forbidding viewpoint discrimination) or Equal Protection (forbidding discrimination on the basis of religion). If viewpoint discrimination and equal protection provide a basis for challenging the exclusion of religious groups from public support, prior decisions treating religion differently from other subjects would also be cast in doubt. ${ }^{46}$ The ripples of change from revisions in religion doctrines spill over into other areas of constitutional analysis without an obvious stopping point for constitutional change.

\section{PuZZLE III: FEDERALISM}

The third puzzle involves federalism, a term whose own ambivalent legal meaning hints at the tension. Federalism-a system of governing divided between central and local authorities - can emphasize decentralization, with national authority committed to recognizing and at many points deferring to state and local governments. But federalism can also stress the significance of the central government as the overarching system, binding the states and localities into a whole and requiring their acceptance of the national government as the supreme and final authority. The two meanings of federalism reflect the dual faces of the two-tiered governance system in the United States: On the one hand, the division of sovereign authority into state and federal governments is meant to advance liberty and democracy by spreading power and maintaining multiple forums for popular participation; on the other hand, the supremacy accorded to federal law is intended to produce coherence and uniformity on subjects of sufficient importance or in sufficient need.

Again, the issues surrounding school vouchers provides a current disputed context for working out the choice between federal uniformity and respect for state and local

Id. (citations omitted).

45. See Locke v. Davey, 540 U.S. 712 (2004); Frank S. Ravitch, Locke v. Davey and the Lose-Lose Scenario. What Locke Could Have Said, but Didn't, 40 Tulsa L. Rev. 255 (2004).

46. See Gerald E. Dempsey \& Janet N. Petsche, Library Law: Does the First Amendment Allow Libraries to Limit the Public Use of Their Property? http://www.mls.lib.il.us/ennounce/librarylaw/librarylaw_11_06.pdf (Oct. 26, 2006). To be fair, doubt may already be present on the viewpoint discrimination front. Compare Faith C. Church Evangelistic Ministries v. Glover, 462 F.3d 1194 (9th Cir. 2006) (approving library's decision to deny use of its meeting room for worship services) with DeBoer v. Village of Oak Park, 267 F.3d 558, 574 (7th Cir. 2001) (rejecting city policy excluding as viewpoint discrimination and characterizing prayer session as civic event). Whether government can treat religion differently from other activities gives rise to questions about levels of Equal Protection scrutiny and sufficient governmental interests. In Locke, the Court rejected the student's request for strict scrutiny of the exclusion of religious training from the state scholarship program. 540 U.S. 712. Absent such a decision, government actors will be hard-pressed to comply with the Establishment Clause. 
control. That choice is on a collision course in some jurisdictions: Federal constitutional interpretation increasingly frowns on the exclusion of religious schools from public funding available to other secular private schools, while some states forbid any public aid to religious schools. Some state and local governments do not merely choose not to fund religious instruction; their state constitutions prohibit public aid to religious schools, and in some cases, to any religious institution. ${ }^{47}$ Many of these state provisions in part or in whole followed the failed effort of Congressman James Blaine to amend the federal Constitution. ${ }^{48}$ Because James Blaine and many of his supporters expressed antiCatholic views in support of restricting aid to religious institutions, many critics argue that state prohibitions are indelibly marred by anti-Catholic hostility. ${ }^{49}$ The four members of the Supreme Court ready to revise the Establishment Clause test in 2000 were also ready to overturn a state constitution Blaine Amendment. ${ }^{50}$ The full Court has not ruled on the issue-yet.

So the question remains open: Must federal constitutional views of religious liberty, equal protection, and freedom of expression trump state constitutional bans on

47. More than two-thirds of the states limit public funding of religious schools or similar kinds of support. See Thomas Berg et al., School Vouchers: Settled Questions, Continuing Disputes, http://pewforum.org/issues/ files/VoucherPackage.pdf (Nov. 2002).

48. For analyses of these "Blaine Amendments," see Richard Fossey \& Robert LeBlanc, Vouchers for Sectarian Schools after Zelman: Will the First Circuit Expose Anti-Catholic Bigotry in the Massachusetts Constitution? 193 Educ. L. Rptr. 343 (2005); Toby J. Heytens, School Choice and State Constitutions, 86 Va. L. Rev. 117, 123 n. 32 (2000) (identifying the influence of the federal proposal on 29-33 state provisions). See also The Becket Fund for Relig. Liberty, Blaine Amendments: States, http://www.blaineamendments.org/ states/states.html (2003) (linking to provisions in thirty-seven state constitutions). For assessments of the provisions-which include potential thirty-seven state constitutions-compare Kyle Duncan, Secularism's Laws: State Blaine Amendments and Religious Persecution, 72 Fordham L. Rev. 493 (2003) (describing and criticizing 37 state provisions) with Steven K. Green, "Blaming Blaine": Understanding the Blaine Amendment and the "No-Funding" Principle, 2 First Amend. L. Rev. 107 (2003) (defending the provisions). The Becket Fund for Religious Liberty has organized a series of legal challenges to state restrictions on funding religious institutions. See e.g. The Becket Fund for Relig. Liberty, Becket Fund Challenges South Dakota Blaine Amendment, http://www.becketfund.org/index.php/article/90.html (Apr. 24, 2003) (describing Pucket v. Hot Springs Sch. Dist., 2006 WL 120233 (Jan. 17, 2006)).

49 See e g. Joseph P. Viterett1, Choosing Equality: School Choice, The Constitution, and Civil Society 18, 152 (Brookings Instn. Press 1999); Frederick Mark Gedicks, Reconstructing the Blaine Amendments, 2 First Amend. L. Rev. 85, 96 (2003). See generally Philip Hamburger, Separation of Church and State 193-251 (Harvard U. Press 2002); Ira C. Lupu \& Robert W. Tuttle, Zelman's Future: Vouchers, Sectarian Providers, and the Next Round of Constitutional Battles, 78 Notre Dame L. Rev. 917 (2003).

50. The plurality opinion directly rejected state Blaine amendments in these terms:

$[\mathrm{H}]$ ostility to aid to pervasively sectarian schools has a shameful pedigree that we do not hesitate to disavow. Although the dissent professes concern for "the implied exclusion of the less favored," the exclusion of pervasively sectarian schools from government-aid programs is just that, particularly given the history of such exclusion. Opposition to aid to "sectarian" schools acquired prominence in the 1870's with Congress's consideration (and near passage) of the Blaine Amendment, which would have amended the Constitution to bar any aid to sectarian institutions. Consideration of the amendment arose at a time of pervasive hostility to the Catholic Church and to Catholics in general, and it was an open secret that "sectarian" was code for "Catholic." Notwithstanding its history, of course, "sectarian" could, on its face, describe the school of any religious sect, but the Court elıminated this possibility of confusion when it coined the term "pervasively sectarian"-a term which, at that time, could be applied almost exclusively to Catholic parochial schools and which even today's dissent exemplifies chiefly by reference to such schools.

In short, nothing in the Establishment Clause requires the exclusion of pervasively sectarian schools from otherwise permissible aid programs, and other doctrines of this Court bar it. This doctrine, born of bigotry, should be buried now.

Mitchell, 530 U.S. at 828-29 (citations omitted). 
aid to religious schools, where the state or locality offers support to secular schools? Should this be a moment of national supremacy, elevating the emerging constitutional commitments to equal protection and against viewpoint discrimination over state concerns about advancing religion with public aid? Or should state constitutional provisions restricting public aid to religious institutions trigger the federal Constitution's limits on federal government interference with the states? This doctrinal puzzle has given rise to much scholarly debate and ongoing litigation. ${ }^{51}$

The usual conclusion would be federal supremacy in the face of direct conflicts with state law. ${ }^{52}$ The federal and state norms are on a collision course but the collision has not yet happened; the federal courts have not connected the dots between decisions permitting parents to use public vouchers to select religious schools ${ }^{53}$ and forbidding exclusion of religious groups from public funding otherwise generally available. ${ }^{54}$ Courts presented with the problem have ducked it thus far because the specific federal norm governing funding for religious schools remains unclear; courts may also approach the religion and equality issues cautiously to avoid a show down between the federal and state governments. Ironically, during the nineteenth century, the federal government actually made bans on public aid to religious institutions a condition of statehood in some instances. ${ }^{55}$ Currently, states may experiment with voucher plans that include religious schools; the Cleveland plan had enough features and conditions to pass muster, but other plans may not. ${ }^{56}$ So federal law has not been construed definitively to require inclusion of religious schools in public funding schemes. Given the "play in the joints" between Establishment and Free Exercise demands, federal constitutional commitments could permit a state to accord vouchers or scholarships to religious schools, but not compel it to do so. ${ }^{57}$

But problems would persist even if a Supreme Court majority fully announces a federal norm that religious schools must be included in any public funding available to secular schools. The chief difficulty even in the face of a squarely presented conflict between federal and state norms is discerning which norm is more protective of individual rights. The axiom that federal constitutional supremacy should overtake any conflicting state rules is nowhere more welcome and acclaimed than in overcoming state discrimination against minority groups. Yet the bans on public aid to religious schools do not necessarily reflect discrimination against a minority group. Many state

51. See e.g. Pew Forum, Separation of Church and States: An Examination of State Constitutional Limits on Government Funding for Religious Institutions, http://pewforum.org/events/index.php?EventID=45 (Mar. 28, 2003).

52. Romer v. Evans, 517 U.S. 620, 633 (1996). The state courts, though, can be a guardian of federal constitutional protection when challenged by state constitutions. See Reitman v. Mulkey, 387 U.S. 369,373 (1967) (affirming Supreme Court of California judgment ruling that State constitutional amendment initiative erasing statutory protection against racial discrimination in housing denied equal protection of laws under Fourteenth Amendment to the United States Constitution).

53. Zelman, 536 U.S. at 662.

54. Good News Club, 533 U.S. 98; Mitchell, 530 U.S. at 829; Rosenberger, 515 U.S. at 841.

55. See Mark Edward DeForrest, An Overview and Evaluation of State Blaine Amendments: Origins, Scope, and First Amendment Concerns, 26 Harv. J.L. \& Pub. Policy 551, 573 (2003).

56 Zelman, 536 U.S. 639.

57. Compare Locke, 540 U.S. 712 with Zelman, 536 U.S. 639. See also Steven K. Greene, Locke v. Davey and the Limits to Neutrality Theory, 77 Temp. L. Rev. 913 (2004). 
restrictions pre-dated the Blaine initiative; others drew diverse support as ways to protect the conscience of minority religious groups, including Catholics. States can mount compelling interests in refraining from support to religious schools quite apart from any historically anti-Catholic views. ${ }^{58}$ So the elements of bad motive at most would tarnish only some of the state restrictions and even these could well have independent compelling justifications-such as avoiding religious strife-that would save them from this objection.

Moreover, it is not clear whether the ban on support for religious schools is less or more protective of liberty than compelled inclusion of such schools in public aid programs. ${ }^{59}$ The truism that states can be more but not less protective of constitutional rights than the federal government does not obviously point in one direction here. Consider which stance is more protective of federal constitutional rights:

1) Strict separation of religion and government, and strict scrutiny for free exercise; or

2) Government neutrality toward religious and secular activities, requiring no separation, and requiring no accommodation from generally applicable laws? ${ }^{60}$

The first view-which until recently was the federal constitutional framework and remains the standard in many states-finds harms to individual liberty when government mixes with religion or fails to accommodate religious practice as harms to liberty-and hence strictly prohibits public aid to religious institutions while energetically advancing individual free exercise through exemptions from burdening laws. ${ }^{61}$ This view urges

58. See Green, supra n. 48, at 113-28, 135-43; Marc D. Stern, Blaine Amendments, Anti-Catholicism, and Catholic Dogma, 2 First Amend. L. Rev. 153, 166-203 (2003). In Divided by God, Noah Feldman argues that conflicts among adherents of different religions - not simple hostility toward Catholicism—produced state bans on funding religion in schools, and advocates maintaining such bans while allowing more room for public displays of religious symbols. Noah Feldman, Divided by God: America's Church-State Problem-And What We Should Do about It (Farrar, Straus \& Giroux 2004). Alan Wolfe treats this view as audacious and historically plausible, but politically and normatively problematic, because even this compromise treats different religions differently: Those making symbols important benefit, while the ban on public aid hurts religious that rely on institutions, like schools and hospitals, more than others that do not. Alan Wolfe, The State of the Church-State Debate, http://www.slate.com/id/2123459/ (Aug. 1, 2005).

59. A recent work, for example, argues that religious liberty calls for public aid to any school that the government accepts for purposes of the compulsory school laws-but also calls for government regulation to ensure students leam how to rationally reflect on their religious training. See generally Ian MacMullen, Faith in Schools? Autonomy, Citizenship, and Religious Education in the Liberal State (Princeton U. Press 2007). This prescription would enhance the liberty of parents who want to select religious schools and the liberty of students to become equipped to choose their religious beliefs, but would undermine the liberty of those who want to give no aid to religious instruction and those who want to protect religious instruction from state regulation and rational skepticism.

60. These two positions do not exhaust the possibilities. See Kathleen Sullivan, The New Religion and the Constitution, 116 Harv. L. Rev. 1397 (2003); see also the discussion of Sullivan's taxonomy in the text accompanying infra $\mathrm{n} .67$.

61. The federal version of this position prevailed when the Court embraced the standards of Lemon, 403 U.S. 602, and Sherbert, 374 U.S. 398. This view-strong separation and strong accommodation-persists in states. Through state constitutional provisions or statues, thirty-seven states forbid public aid to religious schools; some go further and forbid aid to religious institutions. See Berg, supra n. 47 (summarizing state provisions); see e.g Fla. Const., art. I, § 3 ("No revenue of the state or any political subdivision or agency thereof shall ever be taken from the public treasury directly or indirectly in aid of any church, sect, or religious denomination or in aid of any sectarian institution."); Mass. Const., art. XVIII, $\S 2$.

$[\mathrm{N}] \mathrm{o}$ grant, appropriation or use of public money or property or loan of public credit shall be made 
separation between religion and government in order to protect both; it seeks to protect religious adherents from government pressures and government from religious pressure. It also is meant to protect the liberty of individuals who do not affiliate with religious groups seeking the funds or with any religious group, and to protect everyone from potentially divisive and irreconcilable struggles over public resources. In light of historical lessons from religious conflict, renewed by current events around the world, and religious mobilization permeating U.S. politics, ${ }^{62}$ the wisdom of a constitutional commitment to separate public resources from religiously-inspired politics seems enduring.

Yet, a second view treats exclusion of religion from public benefits as the greater harm to liberty, and hence embraces neutrality as the watchword to measure both acceptable government involvement in religion and refusals to exempt individuals from general laws that may burden their religious exercise. Analogizing religions to racial minorities, advocates of this view emphasize historical discrimination against Catholics or other sects and warn against inadvertent as well as deliberate exclusions. Excluding a specific religion or religion in general echoes past disapproval.

The two views remain alive in debates among advocates, judges, and justices. ${ }^{63}$ To further complicate matters, scholars suggest that the ban on public aid to religious schools reflects a theological rather than a neutral position. ${ }^{64}$ Judges and advocates can be excused for feeling dizzy if asked to discern the floor of federally-guaranteed freedom. Now, it becomes a challenging methodological and substantive question: should the remnant of the separatist view be the guide or instead should the neutrality test govern? Is the required minimum federal permission to include religious schools in public aid or federal mandate to include religious schools in public aid? Which should be the "floor" of required liberty?

If minimally mandated religious freedom and government impartiality means

or authorized by the commonwealth or any political division thereof for the purpose of founding, maintaining or aiding any other school or institution of learning, whether under public control or otherwise, wherein any denominational doctrine is inculcated, or any other school, or any college, infirmary, hospital, institution, or educational, charitable or religious undertaking which is not publicly owned and under the exclusive control, order and superintendence of public officers or public agents.

Id. After the Supreme Court struck down the Religious Freedom Restoration Act-Congressional effort to reestablishing the strict-scrutiny test for potential burdens from general legislation on religious free exercisetwelve states formally passed state laws to ensure in state matters the application of the "compelling interest test" in religious freedom cases (AL, AZ, CT, FL, ID, IL, NM, OK, PA, RI, SC, and TX). Seven more states judicially established a "compelling interest test" for application of state law (KS, MA, MN, OH, VT, WA, WI, and MI). See Christopher J. Klicka, State Religious Freedom Acts, http://www.hslda.org/docs/nche/ 000000/00000083.asp (Jan. 28, 2003). For efforts to work through some related issues, see Thomas C. Berg, State Religious Freedom Statutes in Private and Public Education, 32 U.C. Davis L. Rev. 531 (1999); W. Cole Durham, Jr., State RRFAs and the Scope of Free Exercise Protection, 32 U.C. Davis L. Rev. 665 (1999); Eugene Volokh, Intermediate Questions of Religious Exemptions-A Research Agenda with Test Suites, 21 Cardozo L. Rev. 595 (1999).

62. The familiar divisions over abortion and same-sex marriage are now joined by religıous mobılization around global warming and poverty.

63. See Knippenberg, supra n. 40 (discussing shifts in treatment of religion without a new dominant view).

64. See Richard W. Garnett, The Theology of the Blaine Amendments, 2 First Amend. L. Rev. 45 (2003). Similarly complicating is the religious dimension of the early movements for public schooling in Amenca. See e.g. Charles Glenn, The Myth of the Common School (Institute Contemporary Stud. 2002). 
keeping public support away from religious schools, then states should be able to choose whether to include religious schools in public support programs. Future decisions may require inclusion of religious organizations in federal aid programs, but that still would not answer what the states must do. ${ }^{65}$ Greater freedom does not necessarily come by mandating inclusion of religious programs in state and local public aid. Indeed, the benefits of variety and flexibility afforded by a federalist system may look especially welcome for navigating these difficult issues. The federalist structure has long been celebrated for permitting the states to serve as laboratories of social experimentation, encouraging local political engagement, checking concentrated power, and according latitude for the states to strike their own solutions to hard problems. ${ }^{66}$ That, of course, would require accepting varied answers across the country and contrasts between what federal and state laws prescribe, exposing the tension between federal supremacy and state autonomy. But that flexibility may be helpful as each level of government, in different regions of the country, with different constellations of religious groups, tries to comply with the federal constitutional requirements to refrain from either endorsing any religions or disapproving them.

Reflecting on what the three puzzles share, I will also turn to policy considerations, different ways to combine the puzzles, and the virtues of incremental constitutional decision-making.

\section{A COMMOn Difficulty: The Problems of All or Nothing}

Each of these puzzles presents distinct difficulties; each comes into play now when states and local schemes give aid to public and private schools but exclude religious ones. As a further commonality, each of the puzzles presents a dilemma, with each prong of the dilemma both compelling and unsatisfactory precisely because its selection requires rejecting its alternate. Thus, the puzzling conjunction of the Free Exercise and Establishment doctrines could lead government actors to accommodate free exercise at the cost of government partiality toward religion or else to secure scrupulous government distance from religion at the cost of disfavoring and burdening religious exercise. The second puzzle invites judges to respect the recent precedent, overturning prior precedent, but then the values of stability and predictability usually tied to precedent would justify destabilizing much of the surrounding legal terrain; adhering to precedent in the surrounding areas, in contrast, could require confining the new precedent to a narrow foot-print, which then would cast into doubt the fidelity that stare decisis demands. Federalism's Janus-faced tribute to state autonomy could lead courts to limit federal uniformity and supremacy; full embrace of federal power would nullify state autonomy and the decentralized variety that it enables. The courts must choose between federal and state control in cases of direct collisions, but over time across different issues, the

65. See Stern, supra n. 58, at 157.

66. See e.g. A.E. Dick Howard, Federaltsm, in The Bill of Rights, the Courts, and the Law 335 (3d ed., U. Va. Press 1999); A.E. Dick Howard, The Uses of Federalism: The American Experience, 8 Am. U. J. Intl. L. \& Policy 389 (1993). For a critical view of the scientific metaphors informing some defenses of American federalism, see G. Alan Tarr, Laboratories of Democracy? Brandeis, Federalism, and Scientific Management, $31 \mathrm{~J}$. Federalism 37 (2001). 
federal courts can build a portfolio of state control and federal control decisions.

Working through the relationship between the Establishment and Free Exercise commitments of the First Amendment, it is possible to find more alternatives than a strong view of one and a weak view of the other. A particular situation may call for a solution responsive to the tugs from each direction. Kathleen Sullivan devised this taxonomy showing four possible views, each a permutation of the potentially strong or weak view of each of the constitutional clauses: ${ }^{67}$

1) Ambitious judicial enforcement of both clauses: Strong judicial enforcement of the Establishment Clause and strong judicial enforcement of the Free Exercise clause, ${ }^{68}$ treating religion like a private expressive association deserving ample government protection subject to the caveat that the government itself cannot speak in a religious voice;

2) Restrained judicial review for both clauses: Weak judicial enforcement of the Establishment Clause and weak judicial enforcement of the Free Exercise Clause, ${ }^{69}$ treating religion as an ordinary interest group, allowed to participate freely in politics, gain advantage from political deals and spoils, but secure no special advantage from judicial solicitude;

3) Strong separation of religion and government: Strong judicial enforcement of the Establishment Clause and weak judicial enforcement of the Free Exercise Clause, and viewing religion as a quasi-government, with potential authority over its members, but not deserving subsidy from the government or protection from the rival secular government; and

4) Strong accomodation of religion: Weak judicial enforcement of the Establishment Clause and strong enforcement of the Free Exercise Clause, according religion a status like a discrete and insular minority in need of special judicial protection and accommodation even to the point of government involvement with religion.

Two of these views-1 and 3-would roll back the clock and rule against public aid to schools even in the indirect form of vouchers if that means people are forced against their consciences to pay taxes that support religious instruction. ${ }^{70}$ The two remaining positions-2 and 4-would be compatible with a government voucher program, permitting parents to select religious schools, but only one of them, 4 , would demand courts to order inclusion of religious schools in a legislative or school board plan leaving them out. All three other views would treat that solution as excessive and undue judicial solicitude for religion on either Establishment or Free Exercise grounds. ${ }^{71}$

67. Sullivan, supra n. 60 .

68. This is comparable to option 1. Id. and accompanying text.

69. This is comparable to option 2. Id.

70. See Feldman, supra n. 58.

71. Working out precisely what doctrinal tests advance "weak" or "strong enforcement of each clause 


\section{The Policy Dimensions: Part of Constitutional Analysis?}

What none of these approaches detects, however, is a policy consideration that has constitutional ramifications: The potentially deleterious effect on a diverse and democratic society if, over time, the percentage of children attending private schools increased from the usual ten percent ${ }^{72}$ to approach a majority of the population. That kind of shift would undermine the role of public schools as symbols of equality, opportunity, unity, and democracy. ${ }^{73}$ The vast majority of private schools in the United States pursue specific religious missions, and by definition, they are not open to all nor are they guided by the mission of public schools. A major exodus of students from public to private schools would terminate the role of public schools in forging a shared American experience and identity. The character of the nation itself is at stake if a majority of students pursues that option. Recent experience in Great Britain indicates difficulties ensuring that publicly-funded religious schools contribute to national cohesion. ${ }^{74}$ The potential risk from increasing private school student enrollments does not present an all-or-nothing choice. Private schooling does and must persist as an option in a nation that cherishes religious and parental freedom, and the U.S. Supreme Court long ago recognized a parental right to select private schools as a means to comply with a compulsory school law. ${ }^{75}$ A green light to public funding of vouchers and tax credits redeemable at parochial schools raises, however, the subtle issue of a potential

remains another task. For efforts to work out consistent tests, see Feldman, supra n. 58; Abner S. Greene, The Apparent Consistency of Religion Clause Doctrine, 21 Wash. U. J.L. \& Policy 225 (2006).

72. U.S. Dept. of Educ., The Condition of Education 2007 25, http://nces.ed.gov/pubs2007/2007064.pdf (2007) (private school enrollments have hovered around ten percent). The lion share of these enrollments is in religious schools. Over the past fifteen years, the distribution of students in private schools has shifted some, with fewer in Catholic schools and growth in conservative Christian schools.

Although Roman Catholic schools continue to have the largest share of total private school enrollment, the percentage decreased from 55 to 46 percent because of the decline in the percentage of students enrolled in parochial schools (i.e., run by a parish, not by a diocese or independently). On the other hand, the percentage of students enrolled in Conservative Christian schools increased from 11 to 15 percent. In addition, there was an increase in the percentage of students enrolled in nonsectarian private schools, from 13 to 18 percent. This change in distribution from Roman Catholic to other religious and nonsectarian private schools occurred at both the elementary and secondary levels.

Id.

73. Adam Cohen, A First Report Card on Vouchers, http://www.cnn.com/ALLPOLITICS/time/1999/ 04/19/vouchers.html (Apr. 19, 1999).

Public schools have long held the promise of being America's great equalizer, mixing students of different races, classes and religions in a single student body. At their best, public schools have united diverse groups of students, many of them immigrants, by passing on the nation's shared civic heritage, from George Washington to George Washington Carver. Public schools have the ability to teach democracy simply by being open to all children, and regarding them-and their backgrounds and religions-as equally worthy. "Nobody claims private schools can't teach tolerance, mutual respect and nondiscrimination," says Princeton political science professor Amy Gutmann. "But in public schools, they are taught as much by the mixing of students as they are by the curriculum."

Id.

74. The Muslim News, Benefits of Religious Education Not Realized-UK Schools Watchdog, http://www.muslimnews.co.uk/news/news.php?article=12900 (June 17, 2007) (reporting study by Office for Standards in Education, Children's Services and Skills about the effects of religious education in Great Britain).

75. See Pierce, 269 U.S. 510. 
tipping point. ${ }^{76}$ More individual families are likely to opt for private schools-and as specific towns, cities, and states encourage such options through voucher programs and other aid. The cumulative impact of individual family decisions could well alter the character of schooling and socialization in America.

Patterns of socioeconomic and racial segregation in public schooling already expose the distance between the ideal of the common school and the realities of U.S. public schools as a vehicle for building a shared American experience and equal opportunities for all students. ${ }^{77}$ Some advocates of school vouchers claim that private schools can better advance the critical thinking and social cohesion crucial to democracy than public schooling now does. ${ }^{78}$ But this speculation is unsupported by evidence about the range of religious schools emerging in this country, and it is challenged by increased racial and class segregation in privatized schooling in other countries. Moreover, unless tightly regulated in content and admissions practices, private schools could neglect critical thinking and tolerance altogether. Education expert Richard Kahlenberg comments:

If we want students who think critically, do we really want parents to use public funds to educate their children at institutions handpicked to replicate the parents' private beliefs (about, say, creationism) rather than to expose students to broader possibilities? If we want to teach children what it means to be an American, do we want public funds to subsidize private schools set up especially to appeal, say, to an Armenian population, or to those seeking an Afrocentric curriculum? What about schools that harden religious differences rather than emphasizing commonality? ${ }^{79}$

School choice-whether through magnet and charter schools within the public system or encompassing private schools through voucher programs - can offer avenues for voluntary racial and socio-economic integration, for experimentation, and for competition, but it can also cream away from ordinary public schools the most motivated families and crucial public and private resources. The politicized debate at the national level and complex goals behind the reforms make fair evaluation of existing efforts difficult. ${ }^{80}$ Yet risks of social division, inconsistent standards, and diminished attention

76. See Malcolm Gladwell, The Tipping Point: How Little Things Can Make a Big Difference (Little, Brown \& Co. 2000) (examining "social epidemics," or sudden and often chaotic changes from one state to another).

77. Gary Orfield \& Chungmei Lee, Brown at 50: King's Dream or Plessy's Nightmare? http://www.eric. ed.gov/ERICDocs/data/ericdocs2sql/content_storage_01/0000019b/80/1b/b8/82.pdf (Jan. 2004).

78. See generally Making Good Citizens: Education and Civil Society (Diane Ravitch \& Joseph P. Viteretti eds., Yale U. Press 2003).

79. Richard D. Kahlenberg, Review: Good Schools, Good Citizens, Am. Prospect 37 (Mar. 25, 2002) (available at http://www.equaleducation.org/commentary.asp?opedid=904).

80 See V. Dion Haynes, Congress Lifts Income Limit for Students in Evaluation, Wash. Post B04 (Dec. 12, 2006) (alteration in income-eligibility for participants in federal school voucher plan in District of Columbia produces political disagreements and questions about evaluation); Lois Romano, GOP Unveils School Voucher Plan, Wash. Post A17 (July 19, 2006) (notıng party divisions over the plan); Cecilia Elena Rouse, Private School Vouchers and Student Achievement: An Evaluation of the Milwaukee Parental Choice Program, Q.J. Econ. 553 (May 1998) (finding positive effects on math but not reading scores for participants); Ctr. for Policy Alt., School Vouchers, http://www.stateaction.org/issues/issue.cfm/issue/SchoolVouchers.xml (accessed Sept. 13, 2007); Alan Krueger \& Pei Zhu, Another Look at the New York City Voucher Experiment, $\mathrm{http}: / /$ ers.princeton.edu/workingpapers/1_ers.pdf (Apr. 2003) (rejecting interpretation of study claiming large improvement for voucher participants); Dan Lips \& Evan Feinberg, School Choice: 2006 Progress Report, http://www.heritage.org/Research/Education/bg1970.cfm (Sept. 18, 2006). 
to critical thinking could result if religious schools come to educate $30 \%, 50 \%$, or more children across this diverse nation. Hence, decisions to exclude religious schools from public school choice schemes can reflect judgments about educational concerns quite apart from concerns about religious preference or entanglement.

If impact risk of social harm from a shift toward high levels of religious school enrollments is foreseeable, what role should it play in constitutional analysis? Whether characterized as the ethical strand of constitutional analysis, ${ }^{81}$ or folded into considerations directed by the doctrine, ${ }^{82}$ consideration of the effects of a challenged law or a proposed ruling can be an element of constitutional interpretation. Effects matter not simply because constitutions ultimately are meant to serve societal purposes; effects matter quite specifically in assuring the balance between Establishment Clause and Free Exercise commitments embodied in the Bill of Rights, in protecting the complex relationship between state and federal governments, and in maintaining respect for precedent consistent with changing needs. Each of the puzzles associated with these doctrines requires adjustments over time rather than once-and-for-all solutions; each requires awareness of the effects of the Court's own actions.

The current Supreme Court does not, however, seem headed toward this approach to constitutional method. Instead, prominent members of the Court have revived original intent, literal textualism, and formalist doctrines, and the Court has been turning away from consideration of the effects of a policy in assessing potential Establishment Clause problems, without, however, devising a new dominant view. ${ }^{83}$ Nothing in the language

81. Philip Bobbitt, Constitutional Interpretation 12-22 (Basil Blackwell, Inc. 1991).

82. The Lemon test traditionally included consideration of the effects of the challenged law on the advancement or suppression of religion. Lemon, 403 U.S. 602 . Effects are not directly examined under the emerging doctrinal inquiries that instead test whether the challenged law is neutral or whether a reasonable observer would think that the law endorses religion. Yet even under these inquiries, effects can become relevant-in assessing the baseline against which to check the law for neutrality and in assessing the effects a reasonable observer would perceive to be associated with the law-especially if Justice O'Connor's contributions to the emerging theory retain any force. See Rosenberger, 514 U.S. 819, 846 (O'Connor, J., concurring). See also Frederick Mark Gedicks, Reconstructing the Blaine Amendments, 2 First Amend. L. Rev. 85 (2003) (available at http://ssm.com/abstract=419221) (arguing that neutrality prevents government from conditioning the receipt of social welfare benefits on religious affiliation (or lack thereof), but should not generally prevent government from imposing secular conditions as terms of the benefits).

83. See Knippenberg, supra n 40. In Rosenberger, several justices clashed over their readings of the origin of the amendments and their precursors in James Madison's Memorial and Remonstrance against a Virginia tax levy for support of the established church and Thomas Jefferson's Virginia Bill for Religious Liberty. 515 U.S. 819. Justice Thomas read that history "simply as a prohibition on governmental preferences for some religious faiths over others." Id. at 854 (Thomas, J., concurring) (citations omitted). Justice Souter, in contrast, noted that the bill subject to James Madison's critique itself would have funded religious and nonreligious schools, and hence the objection at the time was directed to any governmental support of religion, even if offered equally to other sects and secular establishments Id at 863 (Souter, Stevens, Ginsburg \& Breyer, JJ., dissenting); see also Lee v. Weisman, 505 U.S. 577 (1992); Douglas Laycock, "Nonpreferential" Aid to Religion: A False Claim About Original Intent, 27 Wm. \& Mary L. Rev. 875 (1986).

Professor Tribe has cast doubt on the utility of looking to the intention of particular framers in discerning enduring meaning of the religion clauses; he has emphasized the importance of keeping in mind the differences between Jefferson's commitment to protect politics from religion and Madison's goal to protect both spheres from one another. Laurence H. Tribe, American Constitutional Law 1158-60 (2d ed., Foundation Press 1988). His cautions about originalism in this context are especially well placed, since most of the contemporary debate would not even have occurred without the Court's decision in 1947 to apply the First Amendment to the states, through the then-innovative theory of incorporation through the Fourteenth Amendment. Everson, 330 U.S. 1. Application of the First Amendment too looks quite different now, given that several states had an official established church when the First Amendment was adopted. See Kathleen 
of the religion clauses offers relevant or specific guidance about whether to consider social effects. It is striking, however, that past doctrinal interpretation of Free Exercise and Anti-Establishment commitments has sustained precisely the pattern of ninety percent public and ten percent private school enrollments that characterized American kindergarten through twelfth-grade education for decades.

\section{Putting the Puzzles Together}

Keeping in mind the question about whether and how likely effects of government subsidies for religious schooling, putting the distinct puzzles together might be helpful. Let us try by combining two at a time:

\section{A. Religion Clauses + Federalism}

Courts could construe the Constitution's religion clauses to leave room for localities and states to decide whether to subsidize religious schools in a larger aid program. Such a conclusion-drawing together the religion clauses puzzle and the federalism puzzle-would acknowledge that there are multiple ways to realize the simultaneous commitments to ensure private religious freedom and protect both government and religion from one another. ${ }^{84}$ Precisely because different people interpret the relations between the clauses differently, the courts should be wary about foreclosing local choice. But this calls for reading the religion clauses with either sufficient confidence to include policy concerns in interpreting the clauses or sufficient humility to make room for democratic and state-level decision-making. ${ }^{85}$

\section{B. $\quad$ Stare Decisis + Federalism}

Thinking simultaneously about the puzzles of stare decisis and federalism can also be helpful here. Both the tradition of deference to precedent in constitutional interpretation and the Constitution's structural provisions offer crucial caution to put brakes on rapid change. Those virtues would be welcome when courts consider state constitutions forbidding public aid to religious schools-and also when local governments themselves consider whether to follow Cleveland's school vouchers initiative and expand public scholarships to private schools. ${ }^{86}$ Adherence to precedent when there is a recent decision reversing one line of cases should, in this spirit, point

Sullivan \& Gerald Gunther, Constitutional Law 1508 (15th ed., Foundation Press 2004).

84. Tribe, supra n. 83, at $1158-60$.

85. The second option resembles the minimalism advocated by Cass Sunstein, One Case at a Time: Judicial Minimalism on the Supreme Court (Harvard U. Press 1999). He defends judicial decision-making focused on reaching low-level, fact-drenched agreement on individual cases while leaving "fundamental issues undecided." $I d$. Yet the shifting treatment of aid to religious schools, and the risk of a "tipping point" quickly shifting school enrollments to private schools-may demand a very different judicial method, one attentive to the cumulative impact of individual decisions. The large substantive and methodological competences for pursuing such an approach may explain the paucity of support for this kind of constitutionalism quite as well as the lack of textual grounding in the constitution.

86. Milwaukee, alongside Cleveland, initiated voucher programs that include religious schools. Evaluation efforts have been as yet inconclusive. Natl. Educ. Assn., School Vouchers: The Emerging Track Record, http://www.nea.org/vouchers/02voutrack.html (Apr. 2002); U.S. Gen. Acctg. Off., School Vouchers: Publicly Funded Programs in Cleveland and Milwaukee, http://www.gao.gov/cgi-bin/getrpt?GAO-01-914 (Apr. 2002). 
broadly to the entire array of precedents, not simply the most recent reversal. In this light, a voucher plan including religious schools is permitted-if parents are the circuitbreaker between public funding and the state, if there are many secular choices, if there is a demonstrated history of public school failure ${ }^{87}$-but the Constitution does not compel inclusion of religious schools in a voucher or other public aid program.

\section{Stare Decisis + Religion Clauses}

A constitution devoted to ordered liberty should advance personal liberty consistent with traditions of public order. In the context of potentially compelled public aid to religious schools, courts could ask whether personal liberty lies with allowing state bans on aid to religion, because these restrictions prevent the state from compelling any taxpayer to aid a religious institution - or instead with equalizing financial incentives so individuals who want to choose religious schooling for their children receive support just as do those who elect secular public school? Each view offers a plausible claim as the floor of minimum liberty, ${ }^{88}$ so sheer invocation of individual liberty not does offer much help here.

Stare decisis in the particular context of personal liberty, though, may offer some help through the notion of individual and societal reliance. Adherence to older precedents matters in the context of protections of personal liberty not simply as an expression of familiar societal resistance to change, but also with due respect for the individual and social practices that grow around the precedents, and the reliance that these patterns reflect and in turn propel. This notion of individual and social reliance animates the Supreme Court's adherence to precedent in Planned Parenthood of Southeastern Pennsylvania v. Casey ${ }^{89}$ and reversal of precedent in Lawrence v. Texas. ${ }^{90}$ In Casey, the joint opinion for a plurality of the Supreme Court justices reasoned that reliance interests undergird judicial respect for precedent where personal liberty is at stake. $^{91}$ That Casey opinion in turn informed the Court's majority in Lawrence when the Court invalidated a Texas statute criminalizing intimate sex acts between members of the same sex and overturned Bowers v. Hardwick. The Lawrence majority relied on Casey both for the recognition of personal liberty under the due process clause and for the caution "when a court is asked to overrule a precedent recognizing a constitutional liberty interest, individual or societal reliance on the existence of that liberty cautions with particular strength against reversing course." 92

In Casey, the Court stressed the reliance by individual women and society when it resisted arguments for reversing Roe $v$. Wade's recognition of a women's fundamental liberty to control reproduction through access to abortion:

[F]or two decades of economic and social developments, people have organized intimate relationships and made choices that define their views of themselves and their places in

87. Zelman, 536 U.S. 639; Agostini, 521 U.S. 203.

88. Id.

89. 505 U.S. 833 (1992).

90. 539 U.S. $558(2003)$.

91. 505 U.S. 833.

92. 539 U.S. 558, 577 (citing Casey, 505 U.S. at 855-56). 
society, in reliance on the availability of abortion in the event that contraception should fail. The ability of women to participate equally in the economic and social life of the Nation has been facilitated by their ability to control their reproductive lives.... The Constitution serves human values, and while the effect of reliance on Roe cannot be exactly measured, neither can the certain cost of overruling Roe for people who have ordered their thinking and living around that case be dismissed. ${ }^{93}$

Implicit here is reliance not only by women, but also by employers and families on the availability of women to the labor force enabled by control over reproduction and childbirth. Also powerfully present, though perhaps less discussed, is the reliance by men, who could count on the availability of abortion as a reason for engaging in sexual intercourse with women without obligations to their female partners even when contraception fails. Generationally-marked shifts not only in sexual relations but also in dating, marriage, and family formation emerged, with both men and women ordering their lives around the presumed availability of abortion. These practices in turn affected the direction of advocacy efforts and public policy. As pro-choice advocates for women and families invested in keeping abortion safe and legal, neither public policy nor civil society developed alternative social and policy structures that would render women's workforce participation compatible with child-bearing, despite the urging of cultural feminists who envisioned

\begin{abstract}
alternative structures-ones that are more hospitable not only to pregnant women but to working parents. On a practical level, what that entails is a cluster of legal regulations, tax incentives ... directed towards a cluster of issues: guaranteed leaves, job security, flexible working schedules, part-time employment, and adequate child care. On a more theoretical level, that agenda implies a broader commitment to traditional female values of collaboration, co-operation, and care taking. Given the role constraints that have limited male as well as female experience, both sexes have a stake in such a reconstructive enterprise. $^{94}$
\end{abstract}

Some pro-life/anti-abortion advocates have supported the same or a very similar vision. ${ }^{95}$ But as most people relied on the social relationships enabled by Roe, neither motivation nor action for such alternatives emerged. The Casey majority concluded that reversing Roe would not alter the economic, social, and sexual mores that emerged precisely because of legalized abortion; the Court concluded that reversal of precedent there instead would simply leave women endangered and burdened. ${ }^{96}$

93. 505 U.S. at 856 (citations omitted). The Casey Court tried to distinguish two key reversals of longstanding precedents because they reflected changes in facts or factual understandings. See id at 861-64 (discussing how West Coast Hotel rejected Lochner's view that unfettered economic markets meet human needs and Brown v. Board of Education rejected Plessy's view that legal segregation does not produce racial stigma for the minority group). This is a curious use of "fact" for in both cases the Court is looking behind ideological claims and putting its own weight behind particular interpretations of social experience. On this basis, advocates could claim that the Court should recognize as "fact" that the separationist approach to the Establishment Clause produced stigmatizing exclusions of religious institutions from public aid.

94. Nancy Cott, What is Feminism? 157 (Juliet Mitchell \& Ann Oakley eds., Pantheon Books 1986).

95. See Kerri-Ann Kiniorski, Work vs. Family, 5 Am. Feminist 3 (1998) (available at http://www.feministsforlife.org/taf/1998/summer/Summer98.pdf).

96. See Catherine A. MacKinnon, The Male Ideology of Privacy: A Feminist Perspective on the Right to Abortion, 17 Radical Am. 23 (July-Aug. 1983) (viewing abortion from a male point of view, leaving women unequal in reproductive and sexual choices). 
Social and economic practices have analogously grown up around the absence of government support for religious schools in the United States. Religious communities have devised their own ways to support these schools-including charitable giving, reinforced by the federal tax code's charitable deduction provision. Those religious schools that welcome people outside the religion also recruit scholarship funds from broader sources. Rather than view these practices as happenstance and mere making-do, constitutional analysts could understand this independence and self-reliance by families and religious communities as crucially important to the vitality of religious life and civil society in America - especially when compared with the European societies where both government financed religious schools and fading religious communities are the norm. ${ }^{97}$ State-run religious institutions in Europe lack autonomy and have been associated with declining support among the populace. If all religious schools become dependent upon state financial support, both their independence and ability to maintain private support would be jeopardized.

Even more fundamentally, religious institutions and practices have evolved in the United States in distinctive directions because of the separation of religion from public schooling as well as the efforts of religious groups to include non-adherents in their own schools. ${ }^{98}$ The evolution of Catholic schools as vital urban institutions serving large numbers of Protestant children of color-and the curricular commitments to ecumenism and citizenship-reveal the reliance of Catholics and non-Catholics alike on the emergence of religious schools as a distinct alternative to public schools. ${ }^{99}$ So perhaps ironically, it is the non-reliance on government that has made religious schools vibrant in America-and judicially-mandated public support could endanger this tradition. ${ }^{100}$ In light of these complex patterns of individual and social reliance, the Lawrence majority and Casey plurality would warn today's constitutional interpreters against construing the

97. See Steven Pfaff, The Religious Divide: Why Religion Seems to be Thriving in the United States and Waning in Europe, in Jeffrey Kopstein \& Sven Steinmo, Growing Apart: America and Europe in the TwentyFirst Century 24 (Cambridge U. Press 2007). Compare Harry Anthony Patrinos, Private Provision and Public Finance: Education in the Netherlands, http://www.ifc.org/ifcext/CHEPublication.nsf/0/ 9f18f7b54fb3b98585256c2c005e2cc3/\$FILE/Netherlands\%20_Private\%20Provision\%20and\%20Public\%20Fi nance.pdf (July 2002) with Christian Smith, American Evangelicalism: Embattled and Thriving (U. Chicago Press 1998). The thriving Catholic institutions are particularly interesting, given the assertion that the Blaine Amendments embody anti-Catholic animus. See Mary J. Oates, The Catholic Philanthropic Tradition in America (Indiana U. Press 1995).

98. Some suggest that the separationist tradition has also contributed, perhaps ironically, to the strong role of religious groups in Amencan politics which in turn sustain distinctive American approaches to the state's relationship with religion:

[A] secular state and a religious polity, they are contingently compatible in the sense that each depends upon the other. Thus, we can have highly vocal and widely mobilized religious politics precisely because there is a separation of church and state where the actual affairs of government are concerned. At the same time, that same separation would be intolerable if there were not ample opportunity elsewhere in the society to exercise and express one's religious preference-or lack of one.

N.J. Demerath \& Karen S. Straight, Religion, Politics, and the State: Cross-Cultural Observations, 47 Cross Currents 16 (1997) (available at http://www.crosscurrents.org/Demerath.htm). See also N.J. Demerath \& Rhys H. Williams, $A$ Bridging of Fatths. Religion and Politics in a New England City (Princeton U. Press 1992).

99. See generally Anthony Bryk, Valerie Lee \& Peter Holland, Catholic Schools and the Common Good (Harvard U. Press 1993).

100. Demerath \& Straight, supra n. 98. 
religion clause and federalism precedents to mandate inclusion of religious schools in programs providing public aid to secular schools. Caution is due especially now, as the country journeys through shifting waters on the treatment of religion in public life. ${ }^{101}$

Respect for stare decisis as a principle means respecting individual and social reliance on past precedent. This means that a new precedent should not unleash rapid expansion of the new development. Caution is especially warranted here, given the many open questions in Establishment and Free Exercise jurisprudence and the risk of the cumulative impact of greater numbers of students schooled in separate (and potentially antagonistic) religious traditions. Together, stare decisis and the religion clauses suggest that courts now should leave room for state-level experimentation and variety rather than a uniform national solution on the issue of compelled public aid to religious schools. ${ }^{102}$ Because the ground rules of public funding shape the link between schooling and an inclusive society and, in turn, the prospects for democratic vitality, individual liberty, and mutual tolerance, the constitutional treatment of public aid to religious schools should avoid radical and rapid shifts.

Hence, as the Supreme Court has directed, ${ }^{103}$ courts should permit government programs that choose to include religious schools within larger aid programs-if the other conditions of individual choice or entirely secular content are met. But these new precedents should not be read so aggressively as to require public support of religious schools when states or localities pursue school choice reforms or other forms of school aid. That requirement would demand considerably new readings of the Free Exercise Clause, freedom of speech, or equal protection; such a requirement would overturn the state constitutional provisions-by some counts, in thirty-seven states ${ }^{104}$ banning direct aid to religious schools.

Letting states and localities either include or exclude religious schools in general

101. See Andrew Sullivan, How Fundamentalism Is Splitting the GOP: Crisis of Faith, 232 New Republic 16 (May 2, 2005); Richard Allen Greene, Religion and Politics in America, http://news.bbc.co.uk/ 2/hi/americas/3658172.stm (last updated Sept. 15, 2004); Scott Keeter, Election '06: Big Changes in Some Key Groups, http://pewresearch.org/pubs/93/election-06-big-changes-in-some-key-groups (Nov. 16, 2006); Pew Forum, Religion and the 2006 Elections, http://pewforum.org/docs/index.php?DocID=174 (accessed Mar. 3, 2008) (reporting findings of religiously-based political divisions from two previous Pew Research Center analyses); Greg Smith et al., Religious Groups View the 2006 Election, http://pewresearch.org/ pubs/99/religious-groups-react-to-the-2006-election (Nov. 27, 2006). The trend is very recent or else social scientists disagree about the trend. See Andrew Kohut et al., The Diminishing Divide: Religion's Changing Role in American Politics (Brookings Instn. Press 2000). American political conflict over secular versus religious values informed grassroots politics both before and after Roe v. Wade. See Robert Post \& Reva Siegel, Roe Rage: Democratic Constitutionalism and Backlash, 42 Har. Civ. Rights-Civ. Libs. L. Rev. 373 (2007).

102. Cf. Sunstein, supra n. 85; Cass Sunstein, Burkean Minimalism, http://papers.ssm.com/sol3/ papers.cfm?abstract_id=880121 (Jan. 2006). A critic may condemn forms of judicial minimalism as unduly conservative and complacent, see Sheldon Gelman, The Hedgehog, the Fox, and the Minimalist: Review of One Case at a Time, 89 Geo. L.J. 2297 (2001), but case-by-case consideration of issues on the cusp of conflictual values and doctrines could instead be devoted to preserving dynamism.

103. Zelman, 536 U.S. 639.

104. The Becket Fund for Relig. Liberty, supra n. 48; The Becket Fund for Relig. Liberty, What Are Blaine Amendments? http://blaineamendments.org/Intro/whatis.html (accessed Mar. 3, 2008). "The Becket Fund for Religious Liberty is a nonprofit, nonpartisan, interfaith, public interest law firm dedicated to protecting the free expression of all religious traditions." The Becket Fund for Relig. Liberty, About Us, http:// www.becketfund.org/index.php/article/82.html?PHPSESSID=deafed85c23el da5b30fe94ea lel e84b (accessed Mar. 3, 2008). 
aid programs also requires preserving the "play-in-the joints" between the Establishment Clause and Free Exercise Clause. Preserving respect for precedents halting direct aid to religious schools demands a cautious reading of recent judicial decisions so that both the old and new decisions receive their due. Permitting states to experiment requires forgoing the uniformity and conclusiveness of a single federal decision.

\section{IN PRAISE OF PARTICULARIZED INCREMENTALISM}

The puzzles addressed here remain puzzling. I take heart from the surprising convergence in the analysis offered here with Larry Tribe's analysis of his three linked riddles. Although he addressed the very difficult puzzles of childhood, suspect classifications, and conclusive presumptions, he concluded that individualized judgments about equality claims about particular children offered the best avenue for navigating the difficulties he examined, especially in a period of moral flux. ${ }^{105}$ Similarly, I conclude here that the Supreme Court should resist an across-the-board solution and allow individual states either to ban funding of religious schools or to include those schools in general funding programs.

Even more affirming of the approach taken here are Professor Tribe's reflections in his grand treatise about constitutional and historical change. The Constitution is binding but its meaning must reflect a "historically connected set of processes," and "deep puzzles of continuity and linkage;"106 each new generation becomes "not only auditors but authors of our own constitutional rules and limits," 107 including the choice to remain-or not to remain-faithful to the Constitution. ${ }^{108}$ Shifts in historical practices can expose doctrinal categories as artificial and in need of change. ${ }^{109}$ No doubt cognizant of the irony, Professor Tribe turns to the historic authority of Justice Oliver Wendell Holmes, Jr., to acknowledge the inevitable contribution of present-day interpreters to the meaning and terms of the Constitution:

[W] hen we are dealing with words that are also a constituent act, like the Constitution of the United States, we must realize that they have called into life a being the development of which could not have been foreseen completely by the most gifted of its begetters. It was enough for them to realize or to hope that they had created an organism; it has taken a

105. See Tribe, supra $\mathrm{n}$. 1, at 35 . Tribe argues that some age-based rules should give way to rebuttal through individualized hearings if the rule involves "(1) the deprivation of liberties ordinarily deemed fundamental and (2) the presence of moral transition-at least if coupled with self-preserving institutional unresponsiveness." Id. at 35. Again, with parallels to the inquiry here, Tribe embraces "tentative, ad hoc approaches" where questions seem unanswerable at present so that courts may "facilitate, and take part in, the evolution of moral-and thus legal-consensus." Id. at 36-37.

106. Laurence Tribe, American Constitutional Law 21 (3d ed., Foundation Press 2000).

107. Id. at 24 .

108. Id.

109. Id. at 70 (discussing interpretations of the Commerce Clause). For Professor Tribe, encounters with social, technological, and legal change should turn the search for constitution continuity reaches to general purposes and goals. While acknowledging new constitutional questions posed by the internet and computers, Professor Tribe wrote: "The text used by the Constitution's authors and ratifiers does not exhaust the values our Constitution recognizes," and he proposed a new amendment to convey that "[t]he technologies familiar to the Constitution's authors and ratifiers similarly do not exhaust the threats against which the Constitution's core values must be protected." Laurence H. Tribe, Keynote Address, The Constitution in Cyberspace (Burlingame, Cal., Mar. 26-28, 1991) (emphasis in original) (available at http://www.sjgames.com/SS/tribe.html). 
century and has cost their successors much sweat and blood to prove that they created a nation. The case before us must be considered in the light of our whole experience and not merely in that of what was said a hundred years ago. 110

Thus, concludes Tribe, "any interpretive method necessarily reflects the embrace of some substantive values not necessarily and unambiguously enacted by the constitutional text." 111 Surely this method would push for consideration of the cumulative effects of its own applications, and resist the calls completely to segregate legal doctrine and policy. ${ }^{112}$ Constitutional doctrine is not a straight-jacket but instead a tool for addressing complex difficulties in light of past resolutions of potentially analogous difficulties, and the normative commitments of past and future generations. This remains a task for judges who may be influenced by popular debates but who must, in the end, do their best to interpret the Constitution in light of text, traditions, and purposes. 113

Perhaps, then, it is not surprising that Laurence Tribe, the treatise-writer, asserted little coherence in constitutional law beyond consistently conflicting tendencies. ${ }^{114}$ The constitutionalism that he salutes-and the constitutionalism that this article means to advance-keeps the process of debate over complex and conflictual values going rather than shutting it down. This means harnessing difficult puzzles for their stimulation and resisting the temptation to close off avenues of analysis and competing sources of norms and decisions. ${ }^{115}$ All-things-considered approaches and individualized decisions are

110. Mo. v. Holland, 252 U.S. 416, 433 (1920) (interpreting the Tenth Amendment to permit the national government to enter into a treaty despite objection by a state and in contrast with prior understandings).

111. Tribe, supra n. 83 , at 71 .

112. Id. (discussing consideration of effects of potential Establishment Clause interpretation on American schooling and society).

113. Thus, mass movements and intellectual debate outside of courts may be helpful, see Robert C. Post \& Reva B. Siegel, Legislative Constitutionalism and Section Five Power: Policentric Interpretation of the Family and Medical Leave Act, 112 Yale L.J. 1943 (2003), but the judicial task of constitutional adjudication must remain as a potential bulwark against popular views. See David J. Barron, A Rejoinder from Professor Barron, http://www.hlpronline.com/2006/09/barron_02.html (Sept. 18, 2006); David J. Barron, What's Wrong with Conservative Constitutionalism? Two Styles of Progressive Constitutional Critique and the Choice They Present, http://www.hlpronline.com/2006/07/barron_01.html (Sept. 18, 2006).

114. In explaining his decision to stop work on his constitutional law treatise, Tribe explained:

It's always possible simply to give an accurate account of Supreme Court decision after decision and to string the decisions together in the form of approximate black letter rules and underlying rationales, but it was never my thought that a treatise of that sort was particularly useful in constitutional law, or at least it wasn't the kind of thing I tried to write in 1978 and again in 1988, when the second edition came out, or in 2000 , when the first part of the third edition came out. I was interested, rather, in presenting a coherent picture of constitutional law as a whole, even recognizing that it's never wholly coherent, that there are always conflicting tendencies, and that any body of doctrine that is the vector sum of nine arrows pulling in somewhat different directions will always represent some kind of compromise.

Interview by Robb London with Laurence Tribe (posted Sept. 13, 2005) (available at http:// www.law.harvard.edu/news/tribe/).

115. For a similar set of commitments stemming from concems about religious and normative meaning, see Robert M. Cover, The Supreme Court 1982 Term: Foreward: Nomos and Narrative, 97 Harv. L. Rev. 4, 16 (1983). For critical views whose very existence might delight a pluralist like Cover, see Thom Brooks, Let a Thousand Nomoi Bloom? Four Problems with Robert Cover's Nomos and Narrative, 2006 Issues Leg. Scholarship 5 (2006), http://www.bepress.com/cgi/viewcontent.cgi?article=1071\&context=ils; Judith Resnik, Living Their Commitments: Paideic Communities, Courts, and Robert Cover, 17 Yale J.L. \& Humanities 17 (2005). 
problematic because they are unpredictable and yet they seem to characterize lay and expert views of wisdom. ${ }^{116}$ Particularized case-by-case judicial attention can include assessment of the cumulative impact of religious schooling on the character of the nation and the predicates for inclusive democracy as well as the balance between state prerogatives and federal demands. Even though case-by-case decision-making allows uncertainty and preserves tensions between lines of doctrine on potential collision courses with one another, it also permits law to evolve with practical responsiveness to the multiple priorities relevant to religion, schooling, and democracy.

116. See Robert J. Sternberg, Wisdom, Intelligence, and Creativity Synthesized (Cambridge U. Press 2003); Wisdom: Its Nature, Origins, and Development (Robert J. Stemberg ed., Cambridge U. Press 1990). 
Tulsa Law Review, Vol. 42 [2006], Iss. 4, Art. 9

938

TULSA LAW REVIEW

[Vol. 42:911 